\title{
STAT3 Hyper-IgE Syndrome-an Update and Unanswered Questions
}

\author{
Christo Tsilifis $^{1,2} \cdot$ Alexandra F. Freeman $^{3} \cdot$ Andrew R. Gennery $^{1,2}(\mathbb{C}$
}

Received: 11 March 2021 / Accepted: 20 April 2021 / Published online: 1 May 2021

(c) The Author(s) 2021

\begin{abstract}
The hyper-IgE syndromes (HIES) are a heterogeneous group of inborn errors of immunity sharing manifestations including increased infection susceptibility, eczema, and raised serum IgE. Since the prototypical HIES description 55 years ago, areas of significant progress have included description of key disease-causing genes and differentiation into clinically distinct entities. The first two patients reported had what is now understood to be HIES from dominant-negative mutations in signal transduction and activator of transcription 3 (STAT3-HIES), conferring a broad immune defect across both innate and acquired arms, as well as defects in skeletal, connective tissue, and vascular function, causing a clinical phenotype including eczema, staphylococcal and fungal skin and pulmonary infection, scoliosis and minimal trauma fractures, and vascular tortuosity and aneurysm. Due to the constitutionally expressed nature of STAT3, initial reports at treatment with allogeneic stem cell transplantation were not positive and treatment has hinged on aggressive antimicrobial prophylaxis and treatment to prevent the development of end-organ disease such as pneumatocele. Research into the pathophysiology of STAT3-HIES has driven understanding of the interface of several signaling pathways, including the JAK-STAT pathways, interleukins 6 and 17, and the role of Th17 lymphocytes, and has been expanded by identification of phenocopies such as mutations in IL6ST and ZNF341. In this review we summarize the published literature on STAT3-HIES, present the diverse clinical manifestations of this syndrome with current management strategies, and update on the uncertain role of stem cell transplantation for this disease. We outline key unanswered questions for further study.
\end{abstract}

Keywords Hyper-IgE $\cdot$ HIES $\cdot$ STAT3 $\cdot \operatorname{IgE} \cdot$ quality of life $\cdot$ vasculopathy $\cdot$ HSCT $\cdot$ Job's syndrome

\section{Introduction}

Hyper-immunoglobulin E syndrome (HIES) due to dominant-negative (DN) mutations in signal transduction and activator of transcription 3 [1,2] (STAT3-HIES), previously Job's syndrome, affects fewer than 1 per million population [3]. The JAK/STAT family of signal transducers comprises of four Janus kinases (JAKs) and seven STATs, collectively

Andrew R. Gennery

a.r.gennery@ncl.ac.uk

1 Paediatric Haematopoietic Stem Cell Transplant Unit, Great North Children's Hospital (GNCH), Royal Victoria Infirmary, Queen Victoria Road, Newcastle upon Tyne NE1 4LP, UK

2 Translational and Clinical Research Institute, Faculty of Medical Sciences, Newcastle University, Newcastle upon Tyne NE2 4HH, UK

3 Laboratory of Clinical Immunology and Microbiology, National Institute of Allergy and Infectious Diseases, National Institutes of Health, Bethesda, MD, USA transducing signals from $>50$ cytokines through transmembrane receptor binding and sequential phosphorylation of a JAK, then a STAT, allowing dimerization and nuclear translocation [4]. The numerous signals transduced through these pathways mean that deleterious mutations cause diverse pathology, including severe combined immunodeficiency, malignancy, autoimmunity, and myeloproliferation $[4,5]$.

Ligands transducing through STAT3 include IL-6, IL-10, IL-11, IL-21, IL-22, and IL-23 [5]; aberrant transduction of these pathways coupled with STAT3's ubiquitous expression explain the multisystem manifestations of this syndrome including dermatitis, pulmonary disease, vasculopathy, and skeletal and connective tissue abnormalities. Management currently centers on prevention and treatment of infections arising from the immune deficit, which classically result from Staphylococcus aureus and Candida. Results from correcting the molecular defect in hematopoietic cells were initially discouraging; recent data, while limited, suggest that stem cell transplantation may ameliorate aspects of the syndrome. 
In this review, we present an update on recent advances in the understanding of STAT3 biology, summarize the immune and extra-immune phenotypes of STAT3-HIES, describe current treatment strategies, including recent publications on the role of hematopoietic stem cell transplantation (HSCT), and outline areas for future study to advance our understanding of this syndrome.

\section{History of STAT3-HIES}

The HIES have historically been defined by the triad of elevated $\operatorname{IgE}$, dermatitis, and recurrent skin and lung infections and include diseases caused by mutations of STAT3 [1, 2], TYK2 [6], PGM3 [7], ZNF341 [8], CARD11 [9], and IL6ST $[10,11]$. However, recent reviews have highlighted that several non-HIES disorders also manifest with raised $\operatorname{IgE}$ and severe infection, while within the HIES group itself there is significant etiological, phenotypic, and immunological variation between disorders [12-14]. Notably, TYK2 deficiency does not always cause hyper-IgE [15]; PGM3 deficiency, a glycosylation defect, causes a broad phenotype that may include hyper-IgE in its spectrum [16]; and DOCK8 deficiency has been re-categorized from HIES to combined immunodeficiency [17], highlighting the challenge of grouping such heterogeneous disorders by the shared feature of raised IgE. The complex history and shifting definitions of HIES may stem from the first case report predating the discovery of IgE by some months [18] and are delineated comprehensively in other reviews $[12,14]$; we focus on the syndrome first denoted as Job's, then renamed as HIES, ADHIES, and latterly STAT3-HIES.

STAT3-HIES was first described in 1966, when Davis et al. described recurrent "cold" abscesses isolating Staphylococcus aureus in two unrelated girls sharing fair skin, eczema, and chronic sinopulmonary infection [19]. The syndrome was named after Job, the biblical figure afflicted with "sore boils from the sole of his foot unto his crown" for its distinctive and severe dermatological manifestations. The combination of recurrent skin abscess and pulmonary infection led to an initial suggestion that this may be a variant of chronic granulomatous disease [20], though subsequent bactericidal studies demonstrated normal in vitro phagocytosis of Staphylococcus [21]: the titular raised IgE was not identified in the index patients until 1971 [22]. Buckley et al.'s subsequent series expanded the phenotype to include chronic mucocutaneous and pulmonary fungal infection [23], impaired in vivo antibody production to novel and vaccinestrain pathogens and diminished lymphocyte stimulation by Candida. This was labeled the "hyper-immunoglobulin E syndrome with recurrent infections," an entity felt to be distinct to Job's syndrome, then still labeled a phagocytic disorder. Subsequently, Buckley and Becker demonstrated a familial link in cases, refuted the previous assertion that the syndrome affected only red-haired females, and unified the two syndromes as one entity [24]. Grimbacher et al.'s series [25] of 30 affected patients and 70 family members defined STAT3-HIES as a multi-system disorder by adding retention of primary dentition, scoliosis, and non-infectious vascular events such as cerebrovascular thromboembolic disease and aneurysms to the syndrome and identifying an autosomal dominant inheritance pattern, allowing distinction from a distinct consanguineous cohort subsequently found to have DOCK8 deficiency [26]. Identification that DN STAT3 mutations underlie the syndrome occurred through two separate groups, led by Minegishi et al. and by Holland et al. [1, 2] and has driven significant research into how disrupted STAT3 signaling generates its broad phenotype. Minegishi et al. identified heterozygous mutations in 8 patients, all located in the DNA-binding domain of STAT3, and all of which displayed loss-of-function dominant-negative effects when co-expressed with wild-type STAT3 [1]. Holland et al. identified heterozygous mutations in 50 patients, which were predicted to directly affect the DNA-binding and SRC homology 2 (SH2) domains [2]. Unlike Minegishi et al., they did not determine the loss-of-function or dominant-negative effects of the mutations. Identification of phenocopies of STAT3-HIES have aided correlation of cytokine to phenotype: biallelic mutations in ZNF341 largely phenocopy STAT3-HIES, due to the protein's role in positively regulating STAT3 transcription [8, 27], while dominant and recessive defects in glycoprotein 130 (GP130, encoded by IL6ST) disturb IL-6 and IL-11 signaling, thereby causing a partial STAT3-HIES phenotype (Fig. 1) [10, 11, 28].

\section{Clinical Spectrum of STAT3-HIES}

Patients with STAT3-HIES commonly present early, with infectious and non-infectious manifestations. Frequency of clinical manifestations from published cohorts are summarized in Table 1, while treatment recommendations, which hinge on prevention of end-organ complications by antimicrobial prophylaxis and aggressive treatment of breakthrough infections, are detailed in Table 2.

\section{Bacterial Infection}

Bacterial infections in STAT3-HIES are common and dominated by Staphylococcus aureus, affecting primarily skin and lungs, though other epithelial sites are also represented. Dermatological infection commonly begins with a newborn papulopustular rash resembling neonatal acne; this is present in $50 \%$ of patients within the first 2 weeks of life and pustulates, exudes pus, and crusts, before developing into eczema [29-31]; this rash isolates Staphylococcus 


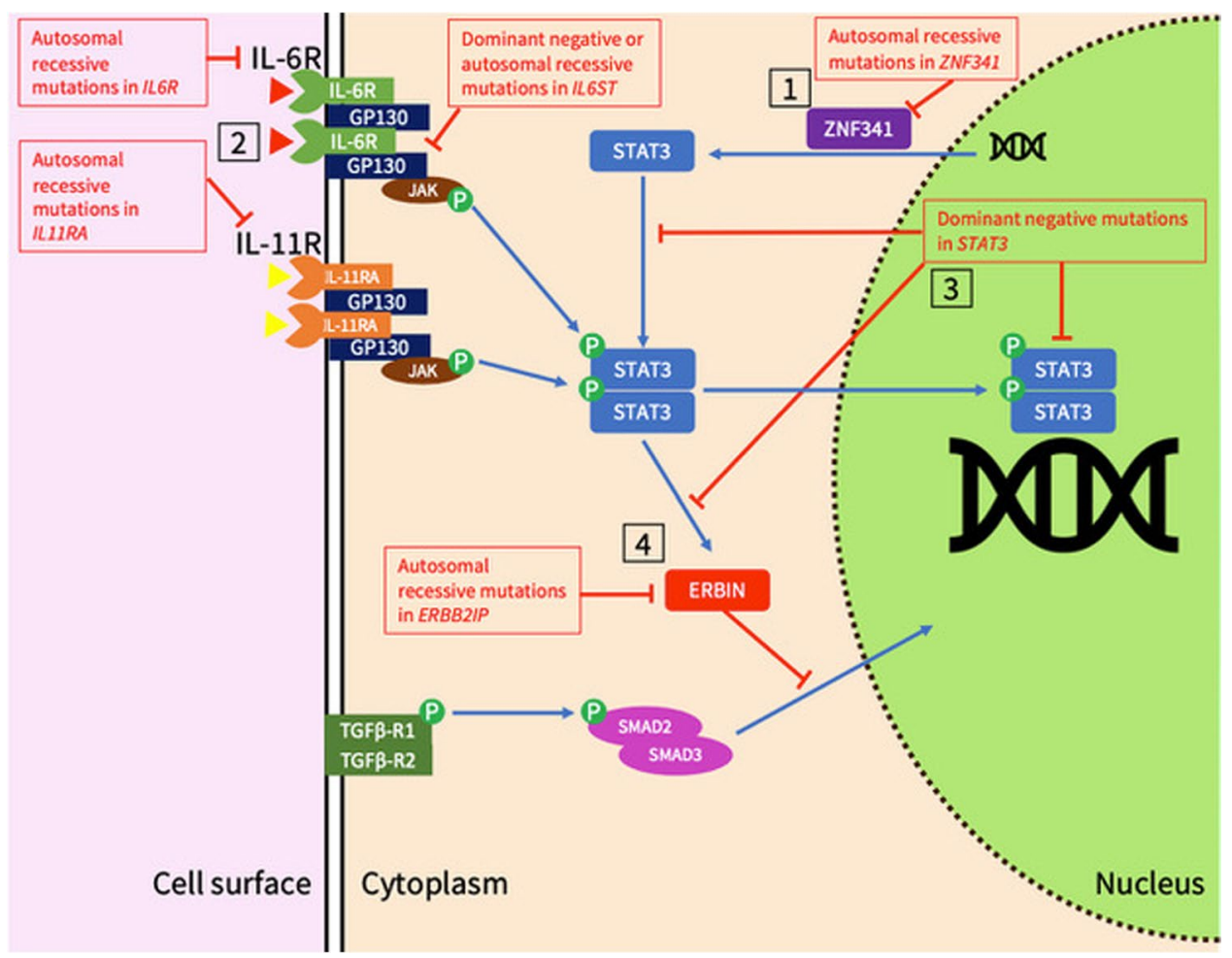

Fig. 1 Mechanisms for disruption of STAT3-related signaling in STAT3-HIES and its phenocopies. 1. ZNF341 positively regulates STAT3 transcription [27]. 2. IL-6 and IL-11 bind to their respective receptors and form a complex with GP130, then sequentially phosphorylate first a JAK, then STAT3. IL-6 signaling may be disrupted by mutations in $I L 6 R$, while IL-11 signaling may be disrupted by $I L 11 R$ mutations, and both may be affected by mutated IL6ST or STAT3. 3. Mutations in the SH2 domain of STAT3 impact tyrosine

aureus and improves with anti-staphylococcal antibiotics, distinguishing it from other neonatal pustuloses [29]. The resultant eczema is present in most patients and becomes colonized with a narrow range of $S$. aureus strains expressing higher prevalence of methicillin resistance and PantonValentine leucocidin [32], probably reflecting a high antibiotic burden exerting selection pressure on skin commensals.

Characteristic "cold" staphylococcal abscess formation is common and may occur in any distribution and can recur despite surgical or radiological drainage, requiring prolonged antibiotic courses [33, 34]. This diminished inflammatory response may result from impaired signaling of IL-6, a key pro-inflammatory cytokine which transduces first through its receptor, then GP130 and STAT3. Unsurprisingly, deleterious mutations in IL6R, IL6ST, and STAT3 overlap in their clinical and immunological manifestations, reflecting IL-6's contribution to STAT3-HIES pathogenesis $[10,11,28,35]$. The reason for the predominance of staphylococcal infection remains unknown but likely relates to deficiency of Th17 lymphocytes, which release antimicrobial peptides and produce the IL-17 cytokine family phosphorylation, while mutations in the DBD domain impact on STAT3 dimers binding to DNA [108]. 4. STAT3 activates ERBIN and disrupts TGF $\beta$-SMAD2/3 signaling by sequestering phosphoSMAD2/3 in the cytoplasm and preventing transcriptional action of TGF $\beta$ [84]. This may be disrupted by mutations in STAT3 or ERBB2IP. Key: STAT3, signal transducer and activator of transcription 3; ERBIN, ERBB2-interacting protein; ZNF341, zinc finger protein 341; GP130, glycoprotein 130

implicated in the response to Staphylococcus aureus, Candida, and gram-negative bacteria [36-39]; their differentiation from naïve CD4 + T-lymphocytes depends on STAT3 [40]. Reduced IL-17 production may explain the predisposition to epithelial site infections: keratinocytes and bronchial epithelial cells require IL-17A for anti-staphylococcal betadefensin secretion [41], and epithelial-site staphylococcal infection occurs in other defects disrupting the IL-17 axis including IL-17RA deficiency [42].

The lungs are the next most common site of infection in STAT3-HIES, usually infected with Staphylococcus, Streptococcus pneumoniae, or Haemophilus influenzae [3, 31], and pulmonary infections contribute significantly to reduced quality of life [43]. Pneumonia is seen in $80 \%$ of patients, frequently recurs, may be complicated by pleural effusion, and commonly provokes development of parenchymal disease including bronchiectasis and pneumatoceles. These provide a nidus for further colonization and subsequent reinfection with an evolving spectrum of pathogens as disease progresses, including Pseudomonas aeruginosa or Aspergillus [44]. Meanwhile, ophthalmic infections, including 


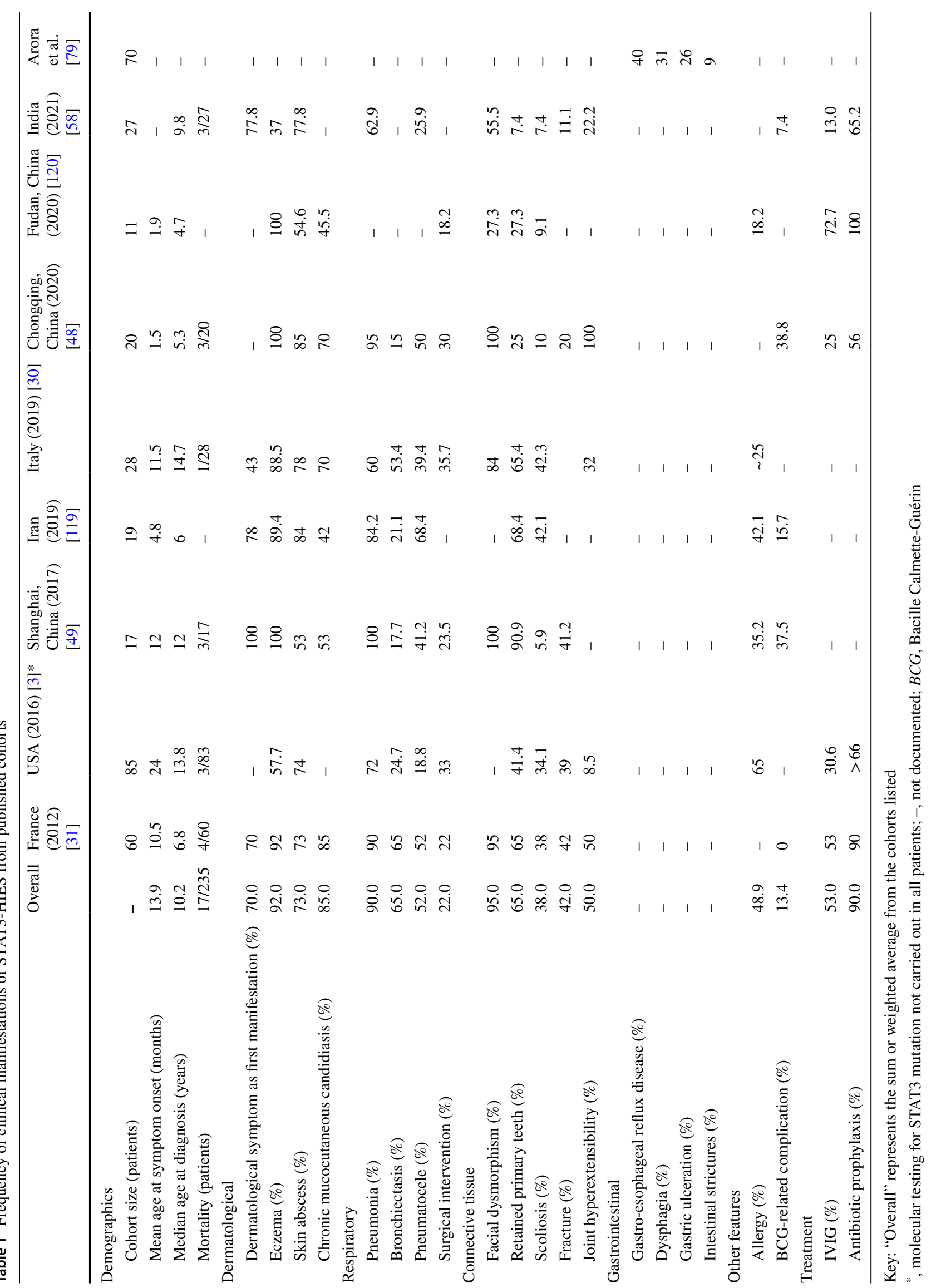




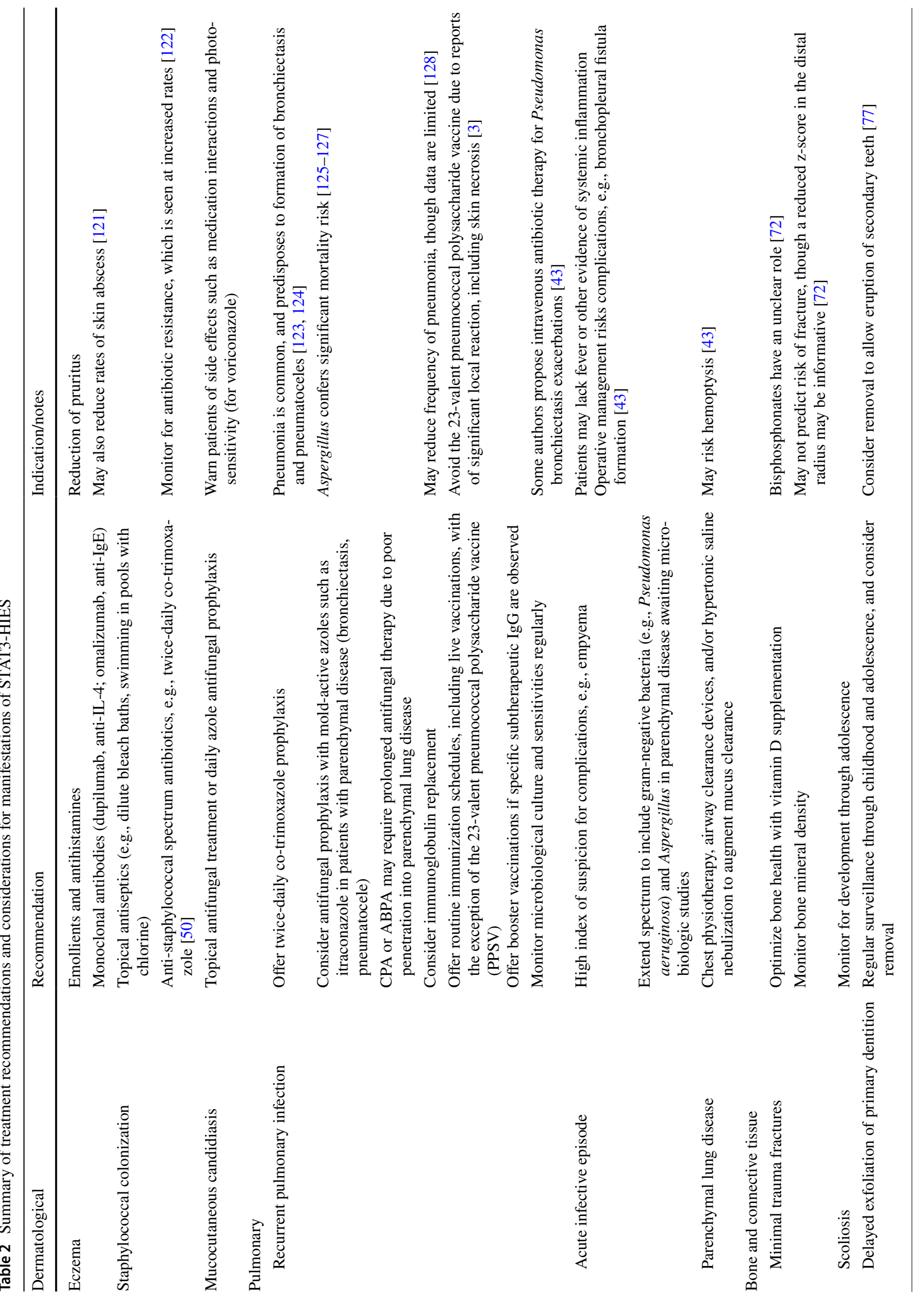


recurrent staphylococcal chalazia and fungal endophthalmitis, are also described [45-47].

Non-epithelial staphylococcal infection, such as liver abscess, is less common than in other defects predisposing to staphylococcal infection such as chronic granulomatous disease. Liver abscess has been described in $\sim 10 \%$ and osteomyelitis and other articular infections in $\sim 20 \%$ of patients [25, 31, 48, 49].

Anti-staphylococcal antibiotic prophylaxis, such as co-trimoxazole, along with antiseptic washes are recommended to prevent both dermatological and pulmonary infection [50].

\section{Fungal Infection}

The Th17/IL-17 axis is implicated in immunity against fungi as well as bacteria, and susceptibility to mucocutaneous Candida infection is promoted by decreased antimicrobial peptides in the saliva of STAT3-HIES patients [51], causing an altered oral microbiome with Candida overgrowth. Chronic mucocutaneous infection occurs in $70 \%$ of patients, typically presenting as oral or genital thrush or onychomycosis [31].

Pulmonary fungal infection, typically by Aspergillus, complicates patients who develop parenchymal disease: all patients in a French cohort [31] with pulmonary Aspergillus had pre-existing lung damage radiologically. Aspergillus may manifest as chronic pulmonary aspergillosis (CPA), most frequently aspergillomas, and allergic bronchopulmonary aspergillosis (ABPA). Criteria for diagnosis of CPA involve consistent appearance on thoracic imaging, microbiological or immunological evidence of Aspergillus, and presence of disease for $\geq 3$ months [52], and treatment may be prolonged due to poor antifungal penetration into pneumatoceles. CPA can be associated with other invasive disease [53] including of vasculature, causing life-threatening hemoptysis and contributing significantly to mortality [54]. ABPA, caused by hypersensitivity to Aspergillus and leading to further bronchiectasis and bronchospasm, is challenging to diagnose due to standardized criteria relying on raised IgE and eosinophilia that may be present in STAT3HIES patients without Aspergillus isolation; diagnosis relies instead on classic imaging findings [55]. Infrequently, Pneumocystis jirovecii may cause the first episode of pneumonia. Antifungals, such as fluconazole, are useful to treat and prevent mucocutaneous Candida, while mold-active antifungals such as itraconazole are considered when parenchymal lung disease is present to prevent CPA and APBA, due to the high mortality associated with Aspergillus infection [35]. Triazoles, such as posaconazole, should be used chronically when pulmonary mold infection is present.

Endemic mycoses can cause disseminated disease: histoplasmosis frequently leads to infection of the 
gastro-intestinal tract and can mimic inflammatory bowel disease. Coccidioides, endemic in the US southwest, can cause severe meningitis and stroke, while Cryptococcus can cause meningitis and has been reported to cause esophageal infection [56]. Prophylaxis against these fungi should be considered for high-risk exposure, such as living in endemic areas.

\section{Mycobacterial Infection}

Local disease may follow Bacille Calmette-Guérin (BCG) vaccination, manifesting as ipsilateral lymphadenitis and suppuration at varying incidence (7.4-39\%, Table 1), though a French registry reported no adverse effects following BCG in their cohort [31]. In the few published reports of disseminated BCG, most patients did not have confirmed STAT3 mutations [57], and in endemic areas such as India tuberculosis-related disease is well-described [58], favoring BCG vaccination in high-prevalence countries. Likewise, disseminated environmental mycobacterial infection is rare, though pulmonary isolation of non-tuberculous mycobacteria (NTM), such as Mycobacterium avium complex and Mycobacterium abscessus, is found at rates comparable to cystic fibrosis (16\% vs 13\%) [59]; all patients with NTM isolation had bronchiectasis, suggesting that parenchymal defects predispose to this expanded spectrum of infective organisms.

\section{Viral Infection}

Severe cutaneous viral infection occurs less commonly than in DOCK8 deficiency, though reactivation of zoster, frequently with disease limited to a single dermatome, occurs in one-third of individuals at a relatively young age; poor immunological memory to varicella may arise from impaired populations of memory CD8 + cytotoxic lymphocytes, which rely on STAT3-dependent IL-10 and IL-21 signaling [60-62]. Similarly, clearance of EBV-infected B-lymphocytes is also impaired, though evidence of translation of this to EBV-related disease is scarce, with most lymphomas being EBV-negative [63].

\section{Non-infectious Manifestations}

\section{Allergy}

Despite elevated IgE, patients with STAT3-HIES demonstrate lower allergy and anaphylaxis rates compared to controls with similar IgE levels and atopic dermatitis, though still increased compared to the general population [64]. Mast cell degranulation is impaired in STAT3-HIES patients [65], and IgE formation is abnormal: it is produced in higher quantities, but to a lower affinity to allergens [66]. The exact mechanism by which hyper-IgE occurs remains unclear, though the elevated $\operatorname{IgE}$ levels seen in dominant and recessive $I L 6 S T$ [10, 28] and recessive $I L 6 R$ [35] mutations support a role for IL-6 in IgE homeostasis. STAT3-HIES patients demonstrate a skew towards IgE + class-switch recombination of memory B-lymphocytes with increased numbers compared to other immunoglobulin classes [67], possibly driven by IL-4, which acts independently of STAT3 [68]. The reduced affinity of STAT3-HIES IgE may result from impaired affinity maturation from direct switching from IgM to IgE production [67]. Common allergens include food, pollen, and drugs, with antibiotic allergy significantly more common in patients with pneumatoceles, possibly due to increased lifetime exposure [3].

\section{Connective Tissue Abnormalities and Poor Wound Healing in STAT3-HIES}

The connective tissue phenotype associated with STAT3HIES varies: the characteristic facies, including a prominent forehead, deep-set eyes, broadened nasal bridge, and high-arched palate, usually develops in adolescence and may not be present in early childhood [69]. Permanent dentition develops appropriately, but there is failure of resorption of the root of primary teeth, which is necessary for eruption, and most children require primary tooth extraction [70]. Joint hyperextensibility occurs in one-third of patients, with degenerative joint disease arising in adulthood, and there is a predisposition to early-onset, minimal trauma long bone fracture. Reduced bone mineral density (BMD) is seen in $79 \%$ but does not correlate to fracture rate: while in classical osteoporosis reduced BMD is seen in the femoral neck and spine [71], in STAT3-HIES only radial BMD correlates with fracture risk [72]. IL-6 signaling through STAT3 inhibits receptor activator of NK- $\mathrm{KB}$-mediated differentiation of macrophages to osteoclasts [73]; subsequently STAT3-HIES patients demonstrate a pro-resorptive state from higher number of osteoclasts than controls [74]. Interestingly, increasing BMD through treatment with anti-osteoclastogenic drugs such as bisphosphonates does not clearly reduce fracture risk, suggesting that other factors contribute [72].

Etiologically, the linkage of these defects to abnormalities in IL- 6 and IL-11 signaling is supported by defects in GP130, which acts as a co-receptor for ligands including IL-6 and IL-11 upstream of STAT3 (Fig. 1), producing a syndrome that phenocopies aspects of STAT3-HIES including recurrent infection, skeletal abnormalities, and raised IgE [10]. The contribution of IL-11 to STAT3-HIES's skeletal phenotype is supported by mutations in ILI1RA causing an overlapping syndrome of craniofacial abnormalities without immunodeficiency [75], demonstrating how phenocopies caused by mutations along the STAT3 axis have shaped understanding of cytokine:phenotype correlation in STAT3-HIES. 
An abnormal response to injury is demonstrated in several tissues, including the lung and gastrointestinal tract. As patients with STAT-HIES age, degenerative arthritis is common, likely secondary to hyperextensible joints and abnormal tissue remodeling. Joint replacements and spine stabilization surgery may be required at relatively younger ages compared to the general population [76]. A high prevalence of complications following thoracic surgery $(\sim 50 \%)$ is seen, the most common being bronchopleural fistula formation, which may chronically discharge and form empyemas in almost half of patients-more frequently than in surgery for similar indications in other patients [77]. Abnormal pulmonary remodeling may result from aberrant expression of matrix metalloproteinases (MMPs) $-3,-8$, and -9 , which are dysregulated in STAT3-HIES [78]; unfortunately, there are no features to prospectively determine risk of complication.

Recent reports include other epithelial sites being affected, including intestinal perforation (both spontaneous and associated with infection, including extra-gastrointestinal infection) $[79,80]$. Proposed mechanisms include gut dysbiosis from antibiotic therapy, defective IL-6 signaling supported by reports of perforation with IL-6 blockade with tocilizumab [81], and dysregulated TGF- $\beta$ signaling supported by murine models of TGF- $\beta$ knockout [82]. The interaction of STAT3 and TGF- $\beta$ appears important given overlapping phenotypes of STAT3-HIES and Loeys-Dietz syndrome caused by TGFBRI/2 mutations, which manifest with connective tissue disease, raised IgE but an intact Th17 axis [83]. Indeed, IL-6 and IL-11 suppress the TGF- $\beta$ pathway through STAT3 activation and recruitment of ERBIN, sequestering SMAD2/3 in the cytoplasm (Fig. 1) and preventing exertion of TGF- $\beta$ 's transcriptional effects [84]: overlap in symptoms and TGF- $\beta$ dysregulation between STAT3-HIES and ERBIN-deficient patients provides another indicator that IL-6 and IL-11, along with IL-17 and IL-21, are the key disease-associated cytokines in STAT3HIES [84].

\section{Vasculopathy}

Vasculopathy in STAT3-HIES presents challenges to both understanding of pathogenesis and clinical management. Overall, medium-sized arterial abnormalities predominate, particularly in the coronary and intracranial vasculature; $50 \%$ of patients in a prospective study had coronary artery abnormalities with ectasia and aneurysm predominating [85] and radiographic evidence of small infarcts in some. Tortuosity and ectasia appear to develop with increasing age [86] and may be explained by STAT3-mediated transcription of VEGF and hypoxia-inducible factor (HIF)- $1 \alpha$, whose expression are reduced in STAT3-HIES [87], and through dysregulated MMPs: MMP-8 is specifically implicated in aneurysm formation [88]. CT coronary angiography shows subclinical atherosclerosis at similar rates to patients with coronary arterial disease, although their disease progresses to aneurysm formation, not stenosis [89]. Evidence for hypertension as a driver of arterial disease is scant; it is described in case reports and in 7/9 patients of an NIH cohort with coronary artery disease at ages 30-55 [86], but not in larger cohorts. There also appears to be an interplay between the Th17/IL-17 axis and vasculopathy in humans: murine models demonstrate aneurysm formation from IL17A blockade [85], while blocking HIF-1 $\alpha$ causes coronary vessel abnormalities and prevents Th17 lymphocyte differentiation [87]. However, paucity of evidence of infection in these patients and reports of progressive vascular disease after normalization of the Th17 axis and immunological indices post-HSCT [90] raise further questions about the relative contribution of immune defects in STAT3-HIES to vascular abnormalities and how these may be prevented.

Cerebrovascular aneurysms may be silent or present symptomatically with rupture, causing significant mortality [91]. Management of asymptomatic aneurysms poses a dilemma, as intervention confers significant risk. A significant proportion (86\%) of patients screened with magnetic resonance imaging display focal punctate hyperintense white matter lesions, at an increased frequency compared to agematched individuals without STAT3-HIES [85]. These are associated with arterial hypertension, smoking, silent cerebral infarcts, and vasculitides [92]; their presence in greater number and at a younger age may reflect increased ischemic injury resulting from vasculopathy. Despite this, cognitive and neuro-behavioral profiling suggests no significant difference between patients with STAT3-HIES and population norms, nor between patients with and without imaging abnormalities [92].

Intrathoracic arterial pseudoaneurysms may cause massive hemoptysis necessitating endovascular intervention [93-95]; while Aspergillus infection is implicated in vascular invasion and formation of pseudoaneurysms, the few reported cases and paucity of histological examination make etiological conclusions difficult to draw.

Data on primary prevention of vascular complications in STAT3-HIES are limited, and further study is required; empiric optimization of cardiovascular risk factors is recommended.

\section{Obstetric and Gynecological Health}

Menses may trigger exacerbations of eczema and, less commonly, pulmonary disease. Decisions surrounding contraception are challenging due to interactions with azole antifungals and increasing risk of thromboembolic disease [34]. This may be relevant given the vasculopathy these patients exhibit; alternative methods (such as progesterone-releasing intra-uterine devices) appear to be well-tolerated. Rates of 
miscarriage, both sporadic and recurrent, are increased; reduced STAT3 signaling in the placenta leads to insufficient proliferation of trophoblast cells and implantation failure and is associated with early miscarriage [96, 97]. Pregnancy itself may exacerbate symptoms and provides challenges in continuing antimicrobial prophylaxis due to concerns regarding teratogenicity.

\section{Malignancy and Autoimmunity}

Malignancy in STAT3-HIES occurs in approximately 7\% of patients and is largely hematopoietic in origin, with lymphoma being most commonly described [31], contrasting with DOCK 8 deficiency where malignancy is more common and includes epithelial sites such as skin [43]. There is a skew towards younger age, and B-lymphocyte non-Hodgkin subtypes, though both Hodgkin-type and T-lymphocyte lymphomas are described [98]. Treatment may be complicated by pre-existing increased infection risk compounded by chemotherapy-related myelosuppression.

STAT3-HIES patients may rarely exhibit a lupus-like phenotype associated with antinuclear and anti-double-stranded DNA antibodies [99]. This may progress to end-stage renal disease from lupus nephritis; a low threshold to investigate proteinuria or rising serum creatinine is therefore important.

\section{Investigations}

\section{Genetics of STAT3}

The ubiquitous expression and variety of signals transduced explain the varied phenotype of mutations in STAT3. Key disease-associated components of its structure include a highly-conserved SH2 domain and a DNA-binding domain (DBD), both implicated in loss-of-function and gain-offunction (GOF) syndromes. While DN STAT3 mutations cause STAT3-HIES, the phenotype of GOF mutations varies: somatic mutations are associated with large granular lymphocytic leukemia [100] and germline mutations with a variable syndrome of early-onset multiorgan autoimmunity and lymphoproliferation [101, 102]. Mutations causing STAT3-HIES and STAT3-GOF may affect the same codon $[3,103]$.

STAT3-DN mutations may be inherited or de novo [2] and usually occur as a result of missense or in-frame deletions [1, 50,104], though deep intronic mutations have been described [105]. Penetrance appears complete although intra-familial phenotypes may differ, suggesting that environmental factors, such as infection history, alter the phenotype [106, 107]. Comparison between mutation site and phenotype has yielded only modest differences, with rates of non-immunological features being slightly increased in SH2 mutants [48, 106, 108]. While 118 mutations are attributed to "hyper-IgE syndrome" or "STAT3 deficiency" in the Human Gene Mutation Database, few variants had been functionally demonstrated to impair STAT3 function; however, a recent report examined all variants described to cause STAT3-HIES and found functionally that the mutations, including both in-frame and out-of-frame, were indeed dominant negative [109].

\section{Laboratory Analysis}

Serum IgE is invariably raised, although it can decrease and even normalize over time, and eosinophilia is typical. Memory T- and B-lymphocyte populations are reduced; B-lymphocyte maturation into memory B-lymphocytes is dependent on pathways transduced through STAT3, including IL-21 and the follicular T-lymphocyte subset [110, 111], resulting in attenuated humoral responses to recall antigens but usually normal total immunoglobulin concentration. Classically, IL-17-producing Th17 lymphocytes are absent; strategies for immunophenotyping and a summary of laboratory findings are summarized in Table 3.

\section{NIH-HIES Score}

A modified NIH-HIES score (Table 4) $>30$ predicts the presence of STAT3 mutation in patients with serum IgE $>1000 \mathrm{IU} / \mathrm{ml}$ [50]. Given the accumulation of complications as patients' age, this score may underestimate the risk of STAT3-HIES in young children. Genetic testing to identify variants in STAT3 remains the optimal diagnostic investigation, though newly described variants should have their deleterious effect functionally validated prior to attributing pathogenicity.

\section{Quality of Life, Natural History, and Mortality}

Data on the impact on quality of life (QOL) in STAT3-HIES are limited to three series. The largest dataset, from the USIDNET registry, shows that $<25 \%$ describe no impact of their health on QOL [3], though this report was not restricted to patients with STAT3 mutations. Fatigue and depression are common (21\%) and associated with skin and pulmonary infection, as is reduced QOL, similarly to chronic granulomatous disease probands, $\mathrm{X}$-linked female carriers, and $\mathrm{X}$-linked agammaglobulinemia patients, demonstrating significant impact of recurrent infection and hospitalization [112-114]. A second series supports the negative impact of pulmonary symptoms on QOL, alone or in combination with dermatological disease [43]. The final dataset explores QOL and cognitive ability in 29 STAT3-HIES patients with white 
Table 3 Laboratory investigations in STAT3-HIES

\begin{tabular}{|c|c|}
\hline Investigation & Comments \\
\hline Full blood count & $\begin{array}{l}\text { Eosinophilia in } 70 \% \\
\text { Occasionally, anemia and/or neutropenia }[3,25]\end{array}$ \\
\hline Lymphocyte subsets & $\begin{array}{l}\text { Total lymphocyte count is normal } \\
\text { Reduced memory CD } 19+\text { CD } 27+\text { B-lymphocytes in } 90 \%[3,31,132] \\
\text { Reduced memory T-lymphocytes [34] }\end{array}$ \\
\hline Immunoglobulins & $\begin{array}{l}\text { Total IgA, IgM, IgG normal } \\
\text { Specific IgG to recall antigens is reduced } \\
\text { Raised IgE, usually }>1000 \mathrm{IU} / \mathrm{ml} \text {, which peaks in infancy and may normalize in adulthood [13] }\end{array}$ \\
\hline Specialist immunophenotyping & $\begin{array}{l}\text { Absent IL-17-producing Th17-lymphocytes } \\
\text { Current strategies for identification of Th17-lymphocytes include the CD4 +CD45RA-CXCR5- } \\
\text { CCR6 + T-lymphocyte phenotype [133, 134] or ex vivo staining for IL-17A following stimu- } \\
\text { lation or induction of differentiation of naïve CD4 + T-lymphocytes [3] }\end{array}$ \\
\hline Molecular analysis of STAT3 & $\begin{array}{l}\text { Heterozygous mutations are typically missense or short in-frame deletions; identification of } \\
\text { new variants is complicated by dominant-negative and gain-of-function mutations sharing the } \\
\text { same codon }[3,103] \\
\text { Any identified variant should be confirmed to be deleterious prior to attributing pathogenicity } \\
\text { Panels may include other candidate genes for HIES, e.g., PGM3, IL6ST, and ZNF341 (which is } \\
\text { a recessive phenocopy of STAT3-HIES), or DOCK8 (a combined immunodeficiency sharing } \\
\text { features with HIES) }\end{array}$ \\
\hline
\end{tabular}

matter hyperintensities [92], showing a normal mean score though $20 \%$ of subjects were $>1$ standard deviation below mean in physical and emotional wellbeing scores.

Data on natural history and mortality are limited, due to the few published cohorts with several sources predating molecular confirmation of STAT3-DN mutations [54]. Survival is typically into adulthood. The few series detailing cause of death skew towards younger age (range: 14 months-40 years; median: 20.5 years), primarily from pulmonary infection, particularly fungal, or complications such as pneumatocele [31, 43, 48, 49, 54]. However, with improved antifungals and expectant management, life expectancy appears to be increasing.

\section{The Uncertain Role of HSCT}

HSCT was initially reported as unsuccessful due to progression of extra-immune features and failure to normalize serum IgE levels [115]. Following this, its role appeared more promising in a report describing HSCT as treatment of lymphoma in two patients [116], and a recent review of seven patients demonstrating satisfactory immune reconstitution and improvement in pulmonary and dermatological symptoms [99]. We recently described eight patients, including the original patient described as unsuccessful, with follow-up ranging 1-20 years and $100 \%$ survival with minimal peri-transplant complications [117]. Data from all published patients who have undergone HSCT are summarized in Table 5, and where available demonstrate improvement in rates of infection, resolution of skin disease, and stabilization or improvement of pulmonary function both clinically and radiologically. Immunologically, serum IgE fell and a normal population of IL-17-secreting Th17 lymphocytes has been demonstrated, highlighting that correcting the immune defect is both possible and beneficial to aspects of the syndrome, though the impact on non-immune manifestations such as connective tissue disease and vasculopathy is not well-understood. Notably, one patient experienced an anterior myocardial infarction associated with a coronary artery aneurysm despite normal donor chimerism and a normal Th17/IL-17 axis [118].
Table 4 Revised NIHHIES score for predicting the likelihood of a STAT3 dominant-negative mutation in a patient with serum $\mathrm{IgE}>1000 \mathrm{IU} / \mathrm{ml}$. Modified from Woellner et al. [50]

\begin{tabular}{lllllllll}
\hline Clinical finding & \multicolumn{1}{l}{ Points } & & \multicolumn{4}{l}{ Scaling factor } \\
\cline { 2 - 7 } & 0 & 2 & 4 & 5 & 6 & 8 \\
\hline Pneumonia (X-ray proven, total no.) & None & 1 & 2 & - & 3 & $>3$ & 2.5 \\
Newborn rash & Absent & - & Present & - & - & - & 2.08 \\
Pathological bone fractures (total no.) & None & - & $1-2$ & - & - & $>2$ & 3.33 \\
Characteristic facies & Absent & Mild & - & Present & - & - & 3.33 \\
High-arched palate & Absent & Present & - & - & - & - & 2.5 \\
\hline
\end{tabular}




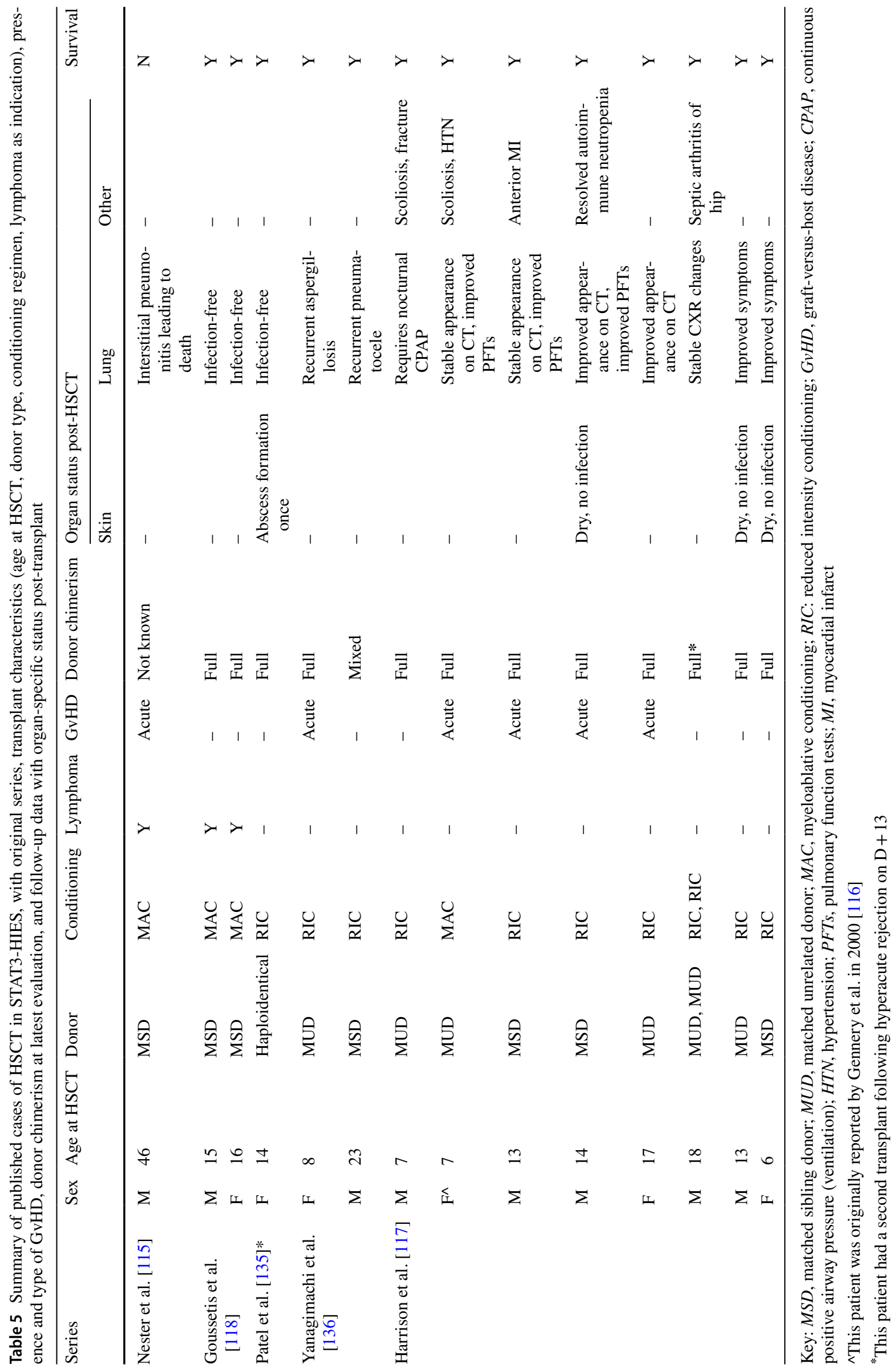




\section{Outstanding Questions}

Recent publications have helped define the pathophysiological mechanisms underlying STAT3-HIES, particularly relating to the contributions of specific cytokines. Extant questions include the natural history of vascular anomalies, the role infection or inflammation have in their development, and how conventional risk factors impact this, in order to inform strategies for primary and secondary prevention. Further studies should explore vasculopathy in this cohort as well as other emerging symptoms, including early-onset degenerative joint and spine disease and intestinal perforation.

Understanding the impact of both infectious and nonimmune manifestations on QOL would inform focus of further treatments. The role of HSCT has only begun to be explored-it would be important to know whether HSCT has any impact on any of the presumed non-immunological manifestations in this cohort. Finally, further gene discovery will likely unveil more phenocopies and add to our understanding of the complex biology of this disease.

\section{CME Review Questions}

Question 1:

Along with STAT3 mutations, which of the following affected genes causing HIES may be inherited in a dominant manner?
A. DOCK8
B. PGM3
C. ZNF341
D. IL6ST
E. IL6R

Question 2:

Which of the following pathogens is not typically associated with STAT3-HIES?
A. Staphylococcus aureus
B. Aspergillus fumigatus
C. Pseudomonas aeruginosa
D. Candida albicans
E. Burkholderia cepacia

Question 3:

Which of the following clinical features suggests an alternative cause of HIES?
A. Vascular abnormalities, including tortuosity
B. Retained primary dentition

C. Severe cutaneous viral infection

D. Abnormalities on CNS imaging

E. Bronchiectasis on cross-sectional thoracic imaging

Question 4:

Which of the following best describes the immunophenotype seen in STAT3-HIES?

A. Normal eosinophil count, normal total lymphocyte count, reduced total $\mathrm{IgG}$, normal IgM

B. Normal eosinophil count, absent lymphocyte count, normal total IgG, normal IgM, presence

C. Raised eosinophil count, normal total lymphocyte count, normal total IgG, normal IgM, absence of IL-17-producing Th17 lymphocytes

D. Raised eosinophil count, reduced total lymphocyte count, reduced total IgG, reduced total IgM

E. Raised eosinophil count, normal total lymphocyte count, reduced total $\mathrm{IgG}$, reduced total $\mathrm{IgM}$, present IL-17-producing Th17 lymphocytes

Question 5:

From available evidence, which factor is most likely to impact on quality of life in patients with STAT3-HIES?
A. Presence of pulmonary symptoms (e.g., dyspnea, reduced exercise tolerance)
B. Presence of connective tissue symptoms (e.g., facial dys- morphism, delayed tooth eruption)
C. Presence of vascular anomalies (e.g., asymptomatic coronary artery aneurysm)
D. Presence of CNS white matter hyperintensities
E. Need for immunoglobulin replacement therapy

Author Contribution CT and ARG conceived the article and prepared the draft manuscript. AF and ARG made editorial changes. All authors contributed to the preparation of this manuscript.

Funding CT is supported by the Job Research Foundation.

Data Availability Not applicable.

Code Availability Not applicable.

\section{Declarations}

Ethics Approval Not applicable.

Consent to Participate Not applicable.

Consent for Publication Not applicable.

Conflict of Interest The authors declare no competing interests. 
Open Access This article is licensed under a Creative Commons Attribution 4.0 International License, which permits use, sharing, adaptation, distribution and reproduction in any medium or format, as long as you give appropriate credit to the original author(s) and the source, provide a link to the Creative Commons licence, and indicate if changes were made. The images or other third party material in this article are included in the article's Creative Commons licence, unless indicated otherwise in a credit line to the material. If material is not included in the article's Creative Commons licence and your intended use is not permitted by statutory regulation or exceeds the permitted use, you will need to obtain permission directly from the copyright holder. To view a copy of this licence, visit http://creativecommons.org/licenses/by/4.0/.

\section{References}

1. Minegishi Y, Saito M, Tsuchiya S, Tsuge I, Takada H, Hara $\mathrm{T}$, et al. Dominant-negative mutations in the DNA-binding domain of STAT3 cause hyper-IgE syndrome. Nature. 2007;448(7157):1058-62.

2. Holland SM, DeLeo FR, Elloumi HZ, Hsu AP, Uzel G, Brodsky $\mathrm{N}$, et al. STAT3 Mutations in the hyper-IgE syndrome. N Engl J Med [Internet]. 2007;357(16):1608-19. Available from: http:// www.nejm.org/doi/abs/10.1056/NEJMoa073687. Accessed Jan 2021.

3. Gernez Y, Freeman AF, Holland SM, Garabedian E, Patel NC, Puck JM, et al. Autosomal dominant hyper-IgE syndrome in the USIDNET Registry. J Allergy Clin Immunol Pract [Internet]. 2018;6(3):996-1001. Available from: https://linkinghub.elsevier. com/retrieve/pii/S2213219817306001. Accessed Jan 2021.

4. Villarino AV, Kanno Y, Shea JJO. Mechanism of JAK/STAT signaling in immunity disease". J Immunol. 2016;194(1):21-7.

5. O'Shea JJ, Holland SM, Staudt LM. JAKs and STATs in immunity, immunodeficiency, and cancer. N Engl J Med. 2013;368(2):161-70.

6. Minegishi Y, Saito M, Morio T, Watanabe K, Agematsu K, Tsuchiya $S$, et al. Human tyrosine kinase 2 deficiency reveals its requisite roles in multiple cytokine signals involved in innate and acquired immunity. Immunity. 2006;25(5):745-55.

7. Sassi A, Lazaroski S, Wu G, Haslam SM, Fliegauf M, Mellouli $\mathrm{F}$, et al. Hypomorphic homozygous mutations in phosphoglucomutase 3 (PGM3) impair immunity and increase serum IgE levels. J Allergy Clin Immunol [Internet]. 2014;133(5):1410-1419. e13. Available from: https://linkinghub.elsevier.com/retrieve/pii/ S0091674914002905. Accessed Jan 2021.

8. Béziat V, Li J, Lin J-X, Ma CS, Li P, Bousfiha A, et al. A recessive form of hyper-IgE syndrome by disruption of ZNF341dependent STAT3 transcription and activity. Sci Immunol [Internet]. 2018;3(24):eaat4956. Available from: https://immun ology.sciencemag.org/lookup/doi/10.1126/sciimmunol.aat49 56. Accessed Jan 2021.

9. Ma CA, Stinson JR, Zhang Y, Abbott JK, Weinreich MA, Hauk PJ, et al. Germline hypomorphic CARD11 mutations in severe atopic disease. Nat Genet [Internet]. 2017;49(8):1192-201. Available from: http://www.nature.com/authors/editorial_polic ies/license.html\#terms. Accessed Jan 2021.

10. Schwerd T, Twigg SRF, Aschenbrenner D, Manrique S, Miller $\mathrm{KA}$, Taylor IB, et al. A biallelic mutation in IL6ST encoding the GP130 coreceptor causes immunodeficiency and craniosynostosis. J Exp Med. 2017;214(9):2547-62.

11. Shahin T, Aschenbrenner D, Cagdas D, Bal SK, Conde CD, Garncarz W, et al. Selective loss of function variants in IL6ST cause hyper-IgE syndrome with distinct impairments of T-cell phenotype and function. Haematologica. 2019;104(3):609-21.
12. Zhang Q, Boisson B, Béziat V, Puel A, Casanova J-L. Human hyper-IgE syndrome: singular or plural? Mamm Genome [Internet]. 2018;29(7-8):603-17. Available from: http://link.springer. com/10.1007/s00335-018-9767-2. Accessed Jan 2021.

13. Freeman AF, Milner JD. The child with elevated IgE and infection susceptibility. Curr Allergy Asthma Rep. 2020;20(11):1-10.

14. Al-Shaikhly T, Ochs HD. Hyper IgE syndromes: clinical and molecular characteristics. Immunol Cell Biol. 2019;97(4):368-79.

15. Kreins AY, Ciancanelli MJ, Okada S, Kong XF, Ramírez-Alejo N, Kilic SS, et al. Human TYK2 deficiency: mycobacterial and viral infections without hyper-IgE syndrome. J Exp Med. 2015;212(10):1641-62.

16. Stray-Pedersen A, Backe PH, Sorte HS, Mørkrid L, Chokshi NY, Erichsen HC, et al. PGM3 mutations cause a congenital disorder of glycosylation with severe immunodeficiency and skeletal dysplasia. Am J Hum Genet. 2014;95(1):96-107.

17. Tangye SG, Al-Herz W, Bousfiha A, Chatila T, CunninghamRundles C, Etzioni A, et al. Human inborn errors of immunity: 2019 update of the IUIS phenotypical classification. J Clin Immunol. 2020;40(1):66-81.

18. Ishizaka K, Ishizaka T, Hornbrook MM. Physicochemical properties of reaginic antibody. V. Correlation of reaginic activity wth gamma-E-globulin antibody. J Immunol. 1966;97(6):840-53.

19. Davis S, Schaller J, Wedgwood R, Harvard MD. Job's syndrome. Lancet [Internet]. 1966;287(7445):1013-5. Available from: http://www.ncbi.nlm.nih.gov/pubmed/4161105. Accessed Jan 2021.

20. Bannatyne RM, Skowron PN, Weber JL. Job's syndromea variant of chronic granulomatous disease. J Pediatr. 1969;75(2):236-42.

21. Davis SD, Iannetta A, Kaplan EL. Job's syndrome and chronic granulomatous disease. J Pediatr [Internet]. 1970;76(1):159-60. Available from: https://linkinghub.elsevier.com/retrieve/pii/ S0022347670801524. Accessed Jan 2021.

22. Pabst HF, Holmes B, Quie PG, Gewurz H, Rodey G, Good RA. Immunological abnormalities in Job's syndrome. Pediatr Res [Internet]. 1971;5(8):380. Available from: http://www.nature. com/doifinder/https://doi.org/10.1203/00006450-19710800000038. Accessed Jan 2021.

23. Buckley RH, Wray BB, Belmaker EZ. Extreme hyperimmunoglobulinemia E and undue susceptibility to infection. Pediatrics [Internet]. 1972;49(1):59 LP - 70. Available from: http://pedia trics.aappublications.org/content/49/1/59.abstract. Accessed Jan 2021.

24. Buckley RH, Becker WG. Abnormalities in the regulation of human IgE synthesis. Immunol Rev [Internet]. 1978;41(1):288314. Available from: http://www.ncbi.nlm.nih.gov/pubmed/ 360511. Accessed Jan 2021.

25. Grimbacher B, Holland SM, Gallin JI, Greenberg F, Hill SC, Malech HL, et al. Hyper-IgE syndrome with recurrent infections - an autosomal dominant multisystem disorder. N Engl J Med [Internet]. 1999;340(9):692-702. Available from: http://www. nejm.org/doi/abs/10.1056/NEJM199903043400904. Accessed Jan 2021.

26. Engelhardt KR, McGhee S, Winkler S, Sassi A, Woellner C, Lopez-Herrera $\mathrm{G}$, et al. Large deletions and point mutations involving the dedicator of cytokinesis 8 (DOCK8) in the autosomal-recessive form of hyper-IgE syndrome. J Allergy Clin Immunol [Internet]. 2009;124(6):1289-1302.e4. Available from: https://linkinghub.elsevier.com/retrieve/pii/S00916749090160 42. Accessed Jan 2021.

27. Frey-Jakobs S, Hartberger JM, Fliegauf M, Bossen C, Wehmeyer ML, Neubauer JC, et al. ZNF341 controls STAT3 expression and thereby immunocompetence. Sci Immunol [Internet]. 2018;3(24):eaat4941. Available from: https://immunology.scien 
cemag.org/lookup/doi/10.1126/sciimmunol.aat4941. Accessed Jan 2021.

28. Béziat V, Tavernier SJ, Chen YH, Ma CS, Materna M, Laurence A, et al. Dominant-negative mutations in human IL6ST underlie hyper-IgE syndrome. J Exp Med. 2020;217(6).

29. Eberting CLD, Davis J, Puck JM, Holland SM, Turner ML. Dermatitis and the newborn rash of hyper-IgE syndrome. Arch Dermatol. 2004;140(9):1119-25.

30. Lorenzini T, Giacomelli M, Scomodon O, Cortesi M, Rivellini V, Dotta L, et al. Autosomal-dominant hyper-IgE syndrome is associated with appearance of infections early in life and/or neonatal rash: evidence from the Italian cohort of 61 patients with elevated IgE. J Allergy Clin Immunol Pract [Internet]. 2019;7(6):2072-2075.e4. Available from: https://doi.org/10. 1016/j.jaip.2019.02.012

31. Chandesris M-O, Melki I, Natividad A, Puel A, Fieschi C, Yun L, et al. Autosomal dominant STAT3 deficiency and hyperIgE syndrome: molecular, cellular, and clinical features from a French national survey. Medicine (Baltimore) [Internet]. 2012;91(4):e1-19. Available from: http://journals.lww.com/ 00005792-201207000-00001. Accessed Jan 2021.

32. Sastalla I, Williams KW, Anderson ED, Myles IA, Reckhow JD, Espinoza-Moraga M, et al. Molecular typing of Staphylococcus aureus isolated from patients with autosomal dominant hyper IgE syndrome. Pathogens. 2017;6(2):1-10.

33. Redor A, Danion F, Parize P, Chandesris O, Dbjay J, Duréault A, et al. Devastating gynecological infections in women with STAT3 deficiency. Clin Infect Dis. 2020;71(7):e186-90. https://doi.org/10.1093/cid/ciaa020.

34. Parisi X, Bergerson J, Urban A, Darnell D, Stratton P, Freeman AF. Obstetric and gynecological care in patients with STAT3deficient hyper IgE syndrome. J Clin Immunol. 2020;17:20-2.

35. Spencer S, Bal SK, Egner W, Allen HL, Raza SI, Ma CA, et al. Loss of the interleukin-6 receptor causes immunodeficiency, atopy, and abnormal inflammatory responses. J Exp Med. 2019;216(9):1986-98.

36. Kolls JK, Lindén A. Interleukin-17 family members and inflammation. Immunity. 2004;21(4):467-76.

37. Bettelli E, Korn T, Kuchroo VK. Th17: the third member of the effector T cell trilogy. Curr Opin Immunol [Internet]. 2007 Dec;19(6):652-7. Available from: https://linkinghub.elsevier. com/retrieve/pii/S0952791507001331

38. Huang W, Na L, Fidel PL, Schwarzenberger P. Requirement of interleukin-17A for systemic anti-Candida albicans host defense in mice. J Infect Dis. 2004;190(3):624-31.

39. Ishigame H, Kakuta S, Nagai T, Kadoki M, Nambu A, Komiyama Y, et al. Differential roles of interleukin-17A and -17F in host defense against mucoepithelial bacterial infection and allergic responses. Immunity [Internet]. 2009;30(1):108-19. Available from: https://doi.org/10.1016/j.immuni.2008.11.009

40. Ma CS, Chew GYJ, Simpson N, Priyadarshi A, Wong M, Grimbacher B, et al. Deficiency of Th17 cells in hyper IgE syndrome due to mutations in STAT3. J Exp Med. 2008;205(7):1551-7.

41. Minegishi Y, Saito M, Nagasawa M, Takada H, Hara T, Tsuchiya S, et al. Molecular explanation for the contradiction between systemic Th17 defect and localized bacterial infection in hyper-IgE syndrome. J Exp Med. 2009;206(6):1291-301.

42. Lévy R, Okada S, Béziat V, Moriya K, Liu C, Chai LYA, et al. Genetic, immunological, and clinical features of patients with bacterial and fungal infections due to inherited IL-17RA deficiency. Proc Natl Acad Sci U S A. 2016;113(51):E8277-85.

43. Kröner C, Neumann J, Ley-Zaporozhan J, Hagl B, Meixner I, Spielberger BD, et al. Lung disease in STAT3 hyper-IgE syndrome requires intense therapy. Allergy Eur J Allergy Clin Immunol. 2019;74(9):1691-702.
44. Freeman AF, Olivier KN. Hyper-IgE syndromes and the lung. Clin Chest Med. 2016;37(3):557-67.

45. Orhan M, Ozkan Y, Irkeç M. Eye involvement in hyperimmunoglobulinemia E (Job's) syndrome. J Pediatr Ophthalmol Strabismus. 2001;38(5):313-4.

46. Haslett RS, Moriarty AP, Vijayadurai P, McGalliard JN, Chandna A. Candida endophthalmitis in Job syndrome. Arch Ophthalmol (Chicago, Ill: 1960) United States. 1996;114:617-8.

47. Destafeno JJ, Kodsi SR, Primack JD. Recurrent Staphylococcus aureus chalazia in hyperimmunoglobulinemia E (Job's) syndrome. Am J Ophthalmol. 2004;138(6):1057-8.

48. Xiang Q, Zhang L, Liu X, Wang S, Wang T, Xiao M, et al. Autosomal dominant hyper IgE syndrome from a single centre in Chongqing, China (2009-2018). Scand J Immunol. 2020;91(6): 1-11.

49. Wu J, Chen J, Tian ZQ, Zhang H, Gong RL, Chen TX, et al. Clinical manifestations and genetic analysis of 17 patients with autosomal dominant hyper-IgE syndrome in mainland China: New Reports and a Literature Review. J Clin Immunol. 2017;37(2):166-79.

50. Woellner C, Michael Gertz E, Schäffer AA, Lagos M, Perro $\mathrm{M}$, Glocker E-O, et al. Mutations in the signal transducer and activator of transcription 3 (STAT3) and diagnostic guidelines for the hyper-IgE syndrome. J Allergy Clin Immunol [Internet]. 2010;125(2):424-32. Available from: https://www.ncbi.nlm.nih. gov/pmc/articles/PMC2878129/pdf/nihms180148.pdf. Accessed Jan 2021.

51. Conti HR, Baker O, Freeman AF, Jang WS, Holland SM, Li RA, et al. New mechanism of oral immunity to mucosal candidiasis in hyper-IgE syndrome. Mucosal Immunol. 2011;4(4):448-55.

52. Denning DW, Cadranel J, Beigelman-Aubry C, Ader F, Chakrabarti A, Blot S, et al. Chronic pulmonary aspergillosis: rationale and clinical guidelines for diagnosis and management. Eur Respir J [Internet]. 2016;47(1):45-68. Available from: https://doi.org/ 10.1183/13993003.00583-2015

53. Vinh DC, Sugui JA, Hsu AP, Freeman AF, Holland SM. Invasive fungal disease in autosomal-dominant hyper-IgE syndrome. J Allergy Clin Immunol [Internet]. 2010;125(6):1389-90. Available from: https://linkinghub.elsevier.com/retrieve/pii/S0091 674910001806. Accessed Jan 2021.

54. Freeman AF, Kleiner DE, Nadiminti H, Davis J, Quezado M, Anderson V, et al. Causes of death in hyper-IgE syndrome. J Allergy Clin Immunol. 2007;119(5):1234-40.

55. Agarwal R, Chakrabarti A, Shah A, Gupta D, Meis JF, Guleria $\mathrm{R}$, et al. Allergic bronchopulmonary aspergillosis: review of literature and proposal of new diagnostic and classification criteria. Clin Exp Allergy [Internet]. 2013 Aug 1;43(8):850-73. Available from: https://doi.org/10.1111/cea.12141

56. Odio CD, Milligan KL, McGowan K, Rudman Spergel AK, Bishop R, Boris L, et al. Endemic mycoses in patients with STAT3-mutated hyper-IgE (Job) syndrome. J Allergy Clin Immunol. 2015;136(5):1411-1413.e2.

57. Metin A, Uysal G, Güven A, Unlu A, Öztürk MH. Tuberculous brain abscess in a patient with hyper IgE syndrome. Pediatr Int. 2004;46(1):97-100.

58. Saikia B, Rawat A, Minz RW, Suri D, Pandiarajan V, Jindal A, et al. Clinical profile of hyper-IgE syndrome in India. Front Immunol. 2021;12:1-9.

59. Melia E, Freeman AF, Shea YR, Hsu AP, Holland SM, Olivier KN. Pulmonary nontuberculous mycobacterial infections in hyper-IgE syndrome. J Allergy Clin Immunol. 2009; 124(3):617-8.

60. Siegel AM, Heimall J, Freeman AF, Hsu AP, Brittain E, Brenchley JM, et al. A critical role for STAT3 transcription factor signaling in the development and maintenance of human T cell memory. Immunity [Internet]. 2011;35(5):806-18. Available from: 
https://linkinghub.elsevier.com/retrieve/pii/S10747613110046 4X. Accessed Jan 2021.

61. Ives ML, Ma CS, Palendira U, Chan A, Bustamante J, BoissonDupuis S, et al. Signal transducer and activator of transcription 3 (STAT3) mutations underlying autosomal dominant hyper-IgE syndrome impair human CD8+ T-cell memory formation and function. J Allergy Clin Immunol. 2013;132(2):400-411.e9.

62. Cui W, Liu Y, Weinstein JS, Craft J, Kaech SM. An interleukin-21-interleukin-10-STAT3 pathway is critical for functional maturation of memory CD8+ $\mathrm{T}$ cells. immunity [Internet]. 2011;35(5):792-805. Available from: https://linkinghub.elsev ier.com/retrieve/pii/S1074761311004651. Accessed Jan 2021.

63. Kumánovics A, Perkins SL, Gilbert H, Cessna MH, Augustine NH, Hill HR. Diffuse large B cell lymphoma in hyperIgE syndrome due to STAT3 mutation. J Clin Immunol. 2010;30(6):886-93.

64. Siegel AM, Stone KD, Cruse G, Lawrence MG, Olivera A, Jung $\mathrm{M}$, et al. Diminished allergic disease in patients with STAT3 mutations reveals a role for STAT3 signaling in mast cell degranulation. J Allergy Clin Immunol. 2013;132(6):1388-1396.e3.

65. Hox V, O'Connell MP, Lyons JJ, Sackstein P, Dimaggio T, Jones N, et al. Diminution of signal transducer and activator of transcription 3 signaling inhibits vascular permeability and anaphylaxis. J Allergy Clin Immunol. 2016;138(1):187-99. https:// doi.org/10.1016/j.jaci.2015.11.024. Erratum in: J Allergy Clin Immunol. 2017;140(1):320.

66. Boos AC, Hagl B, Schlesinger A, Halm BE, Ballenberger N, Pinarci M, et al. Atopic dermatitis, STAT3- and DOCK8-hyperIgE syndromes differ in IgE-based sensitization pattern. Allergy Eur J Allergy Clin Immunol. 2014;69(7):943-53.

67. van de Veen W, Krätz CE, McKenzie CI, Aui PM, Neumann J, van Noesel CJM, et al. Impaired memory B-cell development and antibody maturation with a skewing toward IgE in patients with STAT3 hyper-IgE syndrome. Allergy Eur J Allergy Clin Immunol [Internet]. 2019;74(12):2394-405. Available from: https:// onlinelibrary.wiley.com/doi/abs/10.1111/all.13969. Accessed Jan 2021.

68. Pene J, Rousset F, Briere F, Chretien I, Bonnefoy JY, Spits H, et al. IgE production by normal human lymphocytes is induced by interleukin 4 and suppressed by interferons gamma and alpha and prostaglandin E2. Proc Natl Acad Sci [Internet]. 1988;85(18):6880-4. Available from: http://www.pnas.org/cgi/ doi/10.1073/pnas.85.18.6880. Accessed Jan 2021.

69. Grimbacher B, Schäffer AA, Holland SM, Davis J, Gallin JI, Malech HL, et al. Genetic linkage of hyper-IgE syndrome to chromosome 4. Am J Hum Genet. 1999;65(3):735-44.

70. Meixner I, Hagl B, Kröner CI, Spielberger BD, Paschos E, Dückers G, et al. Retained primary teeth in STAT3 hyper-IgE syndrome: early intervention in childhood is essential. Orphanet $\mathbf{J}$ Rare Dis. 2020;15(1):1-8.

71. Ross PD, Santora A, Yates AJ. Epidemiology and consequences of osteoporotic fractures. Aging Skelet. 1999;359:339-47.

72. Sowerwine KJ, Shaw PA, Gu W, Ling JC, Collins MT, Darnell $\mathrm{DN}$, et al. Bone density and fractures in autosomal dominant hyper IgE syndrome. J Clin Immunol. 2014;34(2):260-4.

73. Duplomb L, Baud'huin M, Charrier C, Berreur M, Trichet V, Blanchard F, et al. Interleukin-6 inhibits receptor activator of nuclear factor $\mathrm{\kappa B}$ ligand-induced osteoclastogenesis by diverting cells into the macrophage lineage: key role of serine 727 phosphorylation of signal transducer and activator of transcription 3 . Endocrinology. 2008;149(7):3688-97.

74. Leung DY, Key L, Steinberg JJ, Young MC, Von Deck M, Wilkinson $\mathrm{R}$, et al. Increased in vitro bone resorption by monocytes in the hyper-immunoglobulin E syndrome. J Immunol. 1988;140(1):84-8.
75. Keupp K, Li Y, Vargel I, Hoischen A, Richardson R, Neveling $\mathrm{K}$, et al. Mutations in the interleukin receptor IL11RA cause autosomal recessive crouzon-like craniosynostosis. Mol Genet Genomic Med. 2013;1(4):223-37.

76. Mitchell AL, Urban AK, Freeman AF, Hammoud DA. An unusual pattern of premature cervical spine degeneration in STAT3LOF. J Clin Immunol [Internet]. 2021. Available from: http:// link.springer.com/10.1007/s10875-020-00926-z. Accessed Mar 2021.

77. Freeman AF, Renner ED, Henderson C, Langenbeck A, Olivier $\mathrm{KN}$, Hsu AP, et al. Lung parenchyma surgery in autosomal dominant hyper-IgE syndrome. J Clin Immunol. 2013;33(5):896-902.

78. Sekhsaria V, Dodd LE, Hsu AP, Heimall JR, Freeman AF, Ding $\mathrm{L}$, et al. Plasma metalloproteinase levels are dysregulated in signal transducer and activator of transcription 3 mutated hyper-IgE syndrome. J Allergy Clin Immunol [Internet]. 2011;128(5):1124 7. Available from: https://linkinghub.elsevier.com/retrieve/pii/ S0091674911012322. Accessed Jan 2021.

79. Arora M, Bagi P, Strongin A, Heimall J, Zhao X, Lawrence MG, et al. Gastrointestinal manifestations of STAT3-deficient hyperIgE syndrome. J Clin Immunol. 2017;37(7):695-700.

80. Bhattacharya S, Williamson H, Urban AK, Heller T, Freeman AF. Spontaneous gastrointestinal perforations in STAT3-deficient hyper-IgE syndrome. J Clin Immunol [Internet]. 2020. Available from: http://link.springer.com/10.1007/s10875-020-008360 . Accessed Jan 2021.

81. Krumbholz M, Meinl E. B cells in MS and NMO: pathogenesis and therapy. Semin Immunopathol. 2014;36(3):339-50.

82. Beck PL, Rosenberg IM, Xavier RJ, Koh T, Wong JF, Podolsky DK. Transforming growth factor- $\beta$ mediates intestinal healing and susceptibility to injury in vitro and in vivo through epithelial cells. Am J Pathol [Internet]. 2003;162(2):597-608. Available from: https://linkinghub.elsevier.com/retrieve/pii/S000294401 0638539. Accessed Jan 2021.

83. Felgentreff K, Siepe M, Kotthoff S, Von Kodolitsch Y, Schachtrup K, Notarangelo LD, et al. Severe eczema and hyperIgE in Loeys-Dietz-syndrome - contribution to new findings of immune dysregulation in connective tissue disorders. Clin Immunol [Internet]. 2014;150(1):43-50. Available from: https://doi. org/10.1016/j.clim.2013.11.008

84. Lyons JJ, Liu Y, Ma CA, Yu X, O'Connell MP, Lawrence MG, et al. ERBIN deficiency links STAT3 and TGF- $\beta$ pathway defects with atopy in humans. J Exp Med. 2017;214(3):669-80.

85. Chandesris Marie-Olivia, Azarine A, Ong KT, Taleb S, Boutouyrie P, Mousseaux E, et al. Frequent and widespread vascular abnormalities in human signal transducer and activator of transcription 3 deficiency. Circ Cardiovasc Genet. 2012;5(1):25-34.

86. Freeman AF, Avila EM, Shaw PA, Davis J, Hsu AP, Welch P, et al. Coronary artery abnormalities in hyper-IgE syndrome. $\mathrm{J}$ Clin Immunol. 2011;31(3):338-45.

87. Dmitrieva NI, Walts AD, Nguyen DP, Grubb A, Zhang X, Wang $\mathrm{X}$, et al. Impaired angiogenesis and extracellular matrix metabolism in autosomal-dominant hyper-IgE syndrome. J Clin Invest. 2020;130(8):4167-81.

88. Pradhan-Palikhe P, Vikatmaa P, Lajunen T, Palikhe A, Lepäntalo M, Tervahartiala T, et al. Elevated MMP-8 and decreased myeloperoxidase concentrations associate significantly with the risk for peripheral atherosclerosis disease and abdominal aortic aneurysm. Scand J Immunol. 2010;72(2):150-7.

89. Abd-Elmoniem KZ, Ramos N, Yazdani SK, Ghanem AM, Holland SM, Freeman AF, et al. Coronary atherosclerosis and dilation in hyper IgE syndrome patients: depiction by magnetic resonance vessel wall imaging and pathological correlation. Atherosclerosis [Internet]. 2017;258:20-5. Available from: https://linkinghub.elsevier.com/retrieve/pii/S00219150173002 42. Accessed Jan 2021. 
90. Ponsford MJ, Clark J, Mock J, Abinun M, Carne E, ElShanawany T, et al. Hematopoietic stem cell transplantation and vasculopathy associated with STAT3-dominant-negative hyperIgE syndrome. Front Pediatr [Internet]. 2020;8(September):1-8. Available from: https://www.frontiersin.org/article/10.3389/fped. 2020.00575/full. Accessed Jan 2021.

91. Nussbaum ES, Torok CM, Carroll J, Gunderman AM. Delayed development of a de novo contralateral middle cerebral artery aneurysm in a patient with hyperimmunoglobulin E syndrome: A case report. Interv Neuroradiol. 2019;25(4):442-6.

92. Martin S, Wolters P, Billings N, Toledo-Tamula MA, Hammoud DA, Welch P, et al. Neurobehavioral profiles in individuals with hyperimmunoglobulin E syndrome (HIES) and brain white matter hyperintensities. J Clin Immunol. 2013;33(7):1175-84.

93. Connolly B, Manson D, Khattak S, Burrows P. Bronchial artery aneurysm in hyperimmunoglobulinemia E syndrome. Pediatr Radiol. 1994;24(8):592-3.

94. Hakim A, Bazan IS, Sanogo ML, Manning EP, Pollak JS, Chupp GL. Pulmonary artery pseudoaneurysm causing massive hemoptysis in hyperimmunoglobulin E syndrome: A case report. BMC Pulm Med. 2019;19(1):1-5.

95. Sharma A, Kumar S, Jagia P. Pulmonary artery pseudoaneurysm in hyper-IgE syndrome: rare complication with successful endovascular management. Vasc Endovascular Surg. 2018;52(5):375-7.

96. Fang Y, Feng X, Xue N, Cao Y, Zhou P, Wei Z. STAT3 signaling pathway is involved in the pathogenesis of miscarriage. Placenta [Internet]. 2020;101(218):30-8. Available from: https://doi.org/ 10.1016/j.placenta.2020.08.021

97. Hiraoka T, Hirota Y, Fukui Y, Gebril M, Kaku T, Aikawa S, et al. Differential roles of uterine epithelial and stromal STAT3 coordinate uterine receptivity and embryo attachment. Sci Rep [Internet]. 2020;10:15523. Available from: https://www.ncbi. nlm.nih.gov/pmc/articles/PMC7511330/. Accessed Jan 2021.

98. Aydin SE, Kilic SS, Aytekin C, Kumar A, Porras O, Kainulainen L, et al. DOCK8 deficiency: clinical and immunological phenotype and treatment options - a review of 136 patients. J Clin Immunol. 2015;35(2):189-98.

99. Oikonomopoulou C, Goussetis E. Autosomal dominant hyperIgE syndrome: when hematopoietic stem cell transplantation should be considered? Pediatr Transplant. 2020;24(5):1-6.

100. Rajala HLM, Porkka K, Maciejewski JP, Loughran TPJ, Mustjoki S. Uncovering the pathogenesis of large granular lymphocytic leukemia-novel STAT3 and STAT5b mutations. Ann Med. 2014;46(3):114-22.

101. Milner JD, Vogel TP, Forbes L, Ma CA, Stray-Pedersen A, Niemela JE, et al. Early-onset lymphoproliferation and autoimmunity caused by germline STAT3 gain-of-function mutations. Blood. 2015;125(4):591-9.

102. Jägle S, Heeg M, Grün S, Rensing-Ehl A, Maccari ME, Klemann C, et al. Distinct molecular response patterns of activating STAT3 mutations associate with penetrance of lymphoproliferation and autoimmunity. Clin Immunol [Internet]. 2020;210:108316. Available from: https://doi.org/10.1016/j.clim.2019.108316

103. Milner JD, Brenchley JM, Laurence A, Freeman AF, Hill BJ, Elias KM, et al. Impaired TH17 cell differentiation in subjects with autosomal dominant hyper-IgE syndrome. Nature [Internet]. 2008;452(7188):773-6. Available from: http://www.nature.com/ articles/nature06764. Accessed Jan 2021.

104. Vogel TP, Milner JD, Cooper MA. The ying and yang of STAT3 in human disease. J Clin Immunol [Internet]. 2015;35(7):615-23. Available from: http://link.springer.com/10.1007/s10875-0150187-8. Accessed Jan 2021.

105. Khourieh J, Rao G, Habib T, Avery DT, Lefèvre-Utile A, Chandesris MO, et al. A deep intronic splice mutation of STAT3 underlies hyper IgE syndrome by negative dominance. Proc Natl Acad Sci U S A. 2019;116(33):16463-72.

106. Heimall J, Davis J, Shaw PA, Hsu AP, Gu W, Welch P, et al. Paucity of genotype-phenotype correlations in STAT3 mutation positive hyper IgE syndrome (HIES). Clin Immunol [Internet]. 2011;139(1):75-84. Available from: https://linkinghub.elsevier. com/retrieve/pii/S1521661611000088. Accessed Jan 2021.

107. Wolach O, Kuijpers T, Ben-Ari J, Gavrieli R, Feinstein-Goren N, Alders M, et al. Variable clinical expressivity of STAT3 mutation in hyperimmunoglobulin E syndrome: Genetic and clinical studies of six patients. J Clin Immunol. 2014;34(2):163-70.

108. Renner ED, Rylaarsdam S, Aňover-Sombke S, Rack AL, Reichenbach J, Carey JC, et al. Novel signal transducer and activator of transcription 3 (STAT3) mutations, reduced TH17 cell numbers, and variably defective STAT3 phosphorylation in hyper-IgE syndrome. J Allergy Clin Immunol. 2008;122(1):181-7.

109. Asano T, Khourieh J, Zhang P, Rapaport F, Spaan A, Li J, et al. Human STAT3 variants underlie autosomal dominant hyper IgE syndrome by negative dominance. J Exp Med. 2021 (in press)

110. Ma CS, Deenick EK. Human T follicular helper (Tfh) cells and disease. Immunol Cell Biol [Internet]. 2014;92(1):64-71. Available from: https://doi.org/10.1038/icb.2013.55

111. Avery DT, Deenick EK, Ma CS, Suryani S, Simpson N, Chew GY, et al. B cell-intrinsic signaling through IL-21 receptor and STAT3 is required for establishing long-lived antibody responses in humans. J Exp Med. 2010;207(1):155-71.

112. Battersby AC, Braggins H, Pearce MS, McKendrick F, Campbell M, Burns S, et al. Health-related quality of life and emotional health in X-linked carriers of chronic granulomatous disease in the United Kingdom. J Clin Immunol. 2019;39(2):195-9.

113. Bryan BA, Battersby A, Shillitoe BMJ, Barge D, Bourne H, Flood T, et al. Respiratory health and related quality of life in patients with congenital agammaglobulinemia in the northern region of the UK. J Clin Immunol [Internet]. 2016;36(5):472-9. Available from: https://doi.org/10.1007/s10875-016-0284-3

114. Cole T, McKendrick F, Titman P, Cant AJ, Pearce MS, Cale $\mathrm{CM}$, et al. Health related quality of life and emotional health in children with chronic granulomatous disease: a comparison of those managed conservatively with those that have undergone haematopoietic stem cell transplant. J Clin Immunol [Internet]. 2013;33(1):8-13. Available from: http://link.springer.com/10. 1007/s10875-012-9758-0. Accessed Jan 2021.

115. Nester TA, Wagnon AH, Reilly WF, Spitzer G, Kjeldsberg CR, Hill HR. Effects of allogeneic peripheral stem cell transplantation in a patient with Job syndrome of hyperimmunoglobulinemia $\mathrm{E}$ and recurrent infections. Am J Med [Internet]. 1998;105(2):1624. Available from: https://linkinghub.elsevier.com/retrieve/pii/ S0002934398002009. Accessed Jan 2021.

116. Gennery A, Flood T, Abinun M, Cant A. Bone marrow transplantation does not correct the hyper IgE syndrome. Bone Marrow Transplant [Internet]. 2000;25(12):1303-5. Available from: http://www.nature.com/articles/1702446. Accessed Jan 2021.

117. Harrison SC, Tsilifis C, Slatter MA, Nademi Z, Worth A, Veys $P$, et al. Hematopoietic stem cell transplantation resolves the immune deficit associated with STAT3-dominant-negative hyperIgE syndrome. J Clin Immunol [Internet]. 2021. Available from: http://link.springer.com/10.1007/s10875-021-00971-2

118. Goussetis E, Peristeri I, Kitra V, Traeger-Synodinos J, Theodosaki M, Psarra K, et al. Successful long-term immunologic reconstitution by allogeneic hematopoietic stem cell transplantation cures patients with autosomal dominant hyper-IgE syndrome. J Allergy Clin Immunol [Internet]. 2010;126(2):392-4. Available from: https://doi.org/10.1016/j.jaci.2010.05.005

119. Tavassoli M, Abolhassani H, Yazdani R, Ghadami M, Azizi G, Abdolrahim Poor Heravi S, et al. The first cohort of Iranian 
patients with hyper immunoglobulin E syndrome: a long-term follow-up and genetic analysis. Pediatr Allergy Immunol. 2019;30(4):469-78.

120. Lin L, Wang Y, Sun B, Liu L, Ying W, Wang W, et al. The clinical, immunological and genetic features of 12 Chinese patients with STAT3 mutations. Allergy, Asthma Clin Immunol [Internet]. 2020;16(1). Available from: https://doi.org/10.1186/ s13223-020-00462-w

121. Simon GL, Miller HG, Scott SJ. Cimetidine in the treatment of hyperimmunoglobulinemia $\mathrm{E}$ with impaired chemotaxis [Internet]. J Infect Dis. 1983;147:1121. Available from: https:// academic.oup.com/jid/article-lookup/doi/10.1093/infdis/147.6. 1121. Accessed Jan 2021

122. Hattori K, Hasui M, Masuda K, Masuda M, Ogino H, Kobayashi Y. Successful trimethoprim-sulfamethoxazole therapy in a patient with hyperimmunoglobulin E syndrome. Acta Paediatr Int J Paediatr. 1993;82(3):324-6.

123. Sogkas G, Hirsch S, Jablonka A, Witte T, Schmidt RE, Atschekzei F. Dupilumab to treat severe atopic dermatitis in autosomal dominant hyper-IgE syndrome. Clin Immunol [Internet]. 2020;215(February):108452. Available from: https://doi.org/ 10.1016/j.clim.2020.108452

124. Gomes N, Miranda J, Lopes S, Carneiro-Leão L, Torres Costa $\mathrm{J}$, Baudrier T, et al. Omalizumab in the treatment of hyper-IgE syndrome: 2 case reports. J Investig Allergol Clin Immunol [Internet]. 2020;30(3):191-2. Available from: http://www.jiaci. org/summary/vol30-issue3-num2020. Accessed Jan 2021.

125. Jeppson JD, Jaffe HS, Hill HR. Use of recombinant human interferon gamma to enhance neutrophil chemotactic responses in Job syndrome of hyperimmunoglobulinemia $\mathrm{E}$ and recurrent infections. J Pediatr [Internet]. 1991;118(3):383-7. Available from: http://doi.wiley.com/10.1002/9781118660584.ese12 82. Accessed Jan 2021.

126. Swain SL, Weinberg AD, English M, Huston G. IL-4 directs the development of Th2-like helper effectors. J Immunol. 1990;145(11):3796-806.

127. Aihara Y, Mori M, Katakura S, Yokota S. Recombinant IFNgamma treatment of a patient with hyperimmunoglobulin E syndrome triggered autoimmune thrombocytopenia. J Interf cytokine Res Off J Int Soc Interf Cytokine Res. 1998;18(8):561-3.

128. Flinn AM, Cant A, Leahy TR, Butler KM, Gennery AR. Autosomal dominant hyper IgE syndrome - treatment strategies and clinical outcomes. J Clin Immunol. 2016;36(2):107-9.

129. O'Connell AC, Puck JM, Grimbacher B, Facchetti F, Majorana A, Gallin JI, et al. Delayed eruption of permanent teeth in hyperimmunoglobulinemia E recurrent infection syndrome. Oral Surg Oral Med Oral Pathol Oral Radiol Endod. 2000;89(2):177-85.

130. Hsu AP, Davis J, Puck JM, Holland SM, Freeman AF. STAT3 hyper IgE syndrome [Internet]. Adam MP, Ardinger HH, Pagon RA, Wallace SE, Bean LJH, Stephens K, et al., editors. GeneReviews®. Seattle (WA); p. 1-19. Available from: http://www. ncbi.nlm.nih.gov/pubmed/20301786. Accessed Jan 2021.

131. Falah O, Thwaites SE, Chalmers RTA. Ruptured thoracoabdominal aneurysm in a 27-year-old with hyper IgE syndrome. J Vasc Surg [Internet]. 2012;55(3):830-2. Available from: https://doi. org/10.1016/j.jvs.2011.08.011

132. Schimke LF, Sawalle-Belohradsky J, Roesler J, Wollenberg A, Rack A, Borte M, et al. Diagnostic approach to the hyper-IgE syndromes: Immunologic and clinical key findings to differentiate hyper-IgE syndromes from atopic dermatitis. J Allergy Clin Immunol [Internet]. 2010;126(3):611-617.e1. Available from: https://doi.org/10.1016/j.jaci.2010.06.029

133. Ma CS, Tangye SG. Flow cytometric-based analysis of defects in lymphocyte differentiation and function due to inborn errors of immunity. Front Immunol. 2019;10:1-13.

134. Ma CS, Wong N, Rao G, Avery DT, Torpy J, Hambridge T, et al. Monogenic mutations differentially affect the quantity and quality of $\mathrm{T}$ follicular helper cells in patients with human primary immunodeficiencies. J Allergy Clin Immunol [Internet]. 2015;136(4):993-1006.e1. Available from: https://linkinghub. elsevier.com/retrieve/pii/S0091674915007873. Accessed Jan 2021.

135. Patel NC, Gallagher JL, Torgerson TR, Gilman AL. Successful haploidentical donor hematopoietic stem cell transplant and restoration of STAT3 function in an adolescent with autosomal dominant hyper-IgE syndrome. J Clin Immunol. 2015;35:47985. https://doi.org/10.1007/s10875-015-0167-z.

136. Yanagimachi M, Ohya T, Yokosuka T, Kajiwara R, Tanaka F, Goto $\mathrm{H}$, et al. The potential and limits of hematopoietic stem cell transplantation for the treatment of autosomal dominant hyperIgE syndrome. J Clin Immunol [Internet]. 2016;36(5):511-6. Available from: https://doi.org/10.1007/s10875-016-0278-1

Publisher's Note Springer Nature remains neutral with regard to jurisdictional claims in published maps and institutional affiliations. 